\title{
Critical care outcomes in patients with pre-existing pulmonary hypertension
}

\author{
KB Bauchmuller ${ }^{1 *}$, R Condliffe ${ }^{2}$, C Billings ${ }^{2}$, Y Arunan ${ }^{1}, \mathrm{GH} \mathrm{Mills}^{1}$ \\ From ESICM LIVES 2015 \\ Berlin, Germany. 3-7 October 2015
}

\section{Introduction}

Pulmonary hypertension $(\mathrm{PH})$ has traditionally been associated with a poor prognosis. However, recent advances in the understanding of its pathophysiology have opened new avenues for treatment [1]. Of note, there are few data on outcome of patients with pre-existing $\mathrm{PH}$ managed in critical care.

\section{Objectives}

To assess critical care outcomes in patients with preexisting pulmonary hypertension and evaluate potential predictors of survival.

\section{Methods}

We conducted a retrospective observational study of patients with $\mathrm{PH}$ admitted to the critical care department (CCD) in a UK national pulmonary hypertension referral centre between April 2000 and July 2014. Critical care data on demographics, admission details, physiological and biochemical parameters as well as treatment modalities in the CCD were collected from our electronic patient record system (Metavision). These were amalgamated with data on WHO functional state, right heart catheter examinations and shuttle walk distance from the $\mathrm{PH}$ unit clinical database. Predictors of critical care and hospital survival were assessed using uni- and multivariate logistic regression analysis. Results are expressed as mean \pm SD and odds ratios (OR) with $95 \%$ confidence intervals (CI).

\section{Results}

One hundred and forty seven patients were included in the study, accounting for 169 individual admission episodes to critical care. Baseline demographics and PH data are shown in Table 1.

Medical, surgical and obstetric categories accounted for $79 \%, 14 \%$ and $8 \%$ of admissions. Hospital survival in these subgroups was 65,91 and $85 \%$, respectively. Thirty percent of patients received CPAP, 9\% bilevel NIV, 5\% invasive

Table 1. Baseline characteristics

\begin{tabular}{ll}
\hline Age (years) & $50.5 \pm 17.2$ \\
\hline Sex M/F (\%) & $34 / 66$ \\
\hline PH diagnosis group: 1 (PAH), 2 (Left heart disease), 3 (Lung disease), 4 (CTEPH), 5 (Miscellaneous). (\%) & $64 / 5 / 6 / 17 / 7$ \\
\hline WHO functional class: 1/2/3/4 (\%) & $0 / 13 / 61 / 26$ \\
\hline mRAP (mmHg) & $11.02 \pm 6.88$ \\
\hline mPAP (mmHg) & $47.26 \pm 12.82$ \\
\hline PAWP (mmHg) & $10.89 \pm 4.30$ \\
\hline C (L.min-1.m-2) & $2.81 \pm 1.12$ \\
\hline PVR (dyn.s.cm-5) & $697 \pm 437$ \\
\hline ISWT distance $(\mathrm{m})$ & $205 \pm 158$ \\
\hline
\end{tabular}


Table 2. Admission parameters predicting hospital survival

\begin{tabular}{lllllll}
\hline & \multicolumn{6}{l}{ Univariate } \\
& OR & $95 \% \mathrm{Cl}$ & $\mathrm{p}$ & $\mathrm{OR}$ & $95 \% \mathrm{Cl}$ & $\mathrm{p}$ \\
\hline Age & 0.986 & $(0.967-1.005)$ & 0.15 & & & \\
\hline HR & 1.026 & $(1.009-1.044)$ & 0.003 & & & \\
\hline MAP & 0.980 & $(0.961-1.000)$ & 0.052 & & & \\
\hline Sp02/Fi02 & 0.994 & $(0.990-0.997)$ & 0.001 & 0.994 & $(0.989-0.999)$ & 0.01 \\
\hline Lactate & 1.655 & $(1.252-2.188)$ & $<0.001$ & 1.644 & $(1.244-2.172)$ & $<0.001$ \\
\hline Na+ & 0.920 & $(0.864-0.979)$ & 0.008 & 0.891 & $(0.827-0.959)$ & 0.002 \\
\hline Urea & 1.047 & $(1.008-1.087)$ & 0.019 & & & \\
\hline Platelets & 0.996 & $(0.992-0.999)$ & 0.02 & & & \\
\hline
\end{tabular}

ventilation, $23 \%$ vasopressors, $19 \%$ inotropes and $12 \%$ $\mathrm{CVVH}$. These therapeutic modalities were associated with a hospital survival of $51,47,11,41,34$ and $57 \%$, respectively. Overall, $76 \%$ of patients survived to discharge from critical care and $70 \%$ left hospital alive. Several parameters at admission to the CCD were identified as predictors of hospital discharge at univariate and multivariate logistic regression analysis, most notably $\mathrm{Sp} 02 / \mathrm{Fi} 02$ ratio, serum lactate and serum sodium concentration (see Table 2).

\section{Conclusions}

Overall, more than two thirds of patients with pre-existing $\mathrm{PH}$ admitted to critical care survived to hospital discharge. Medical reasons for admission were associated with a worse outcome compared with surgical and obstetric indications. Independent predictors of hospital mortality were low serum sodium, high lactate and low Sp02/Fi02 ratio, reflecting heart failure, poor cardiac output and poor oxygenation.

\section{Authors' details}

'Sheffield Teaching Hospitals NHS Foundation Trust, Anaesthesia and Critical Care, Sheffield, United Kingdom. ${ }^{2}$ National Pulmonary Hypertension Service,

Pulmonary Vascular Disease Unit, Royal Hallamshire Hospital, Sheffield

Teaching Hospitals NHS Foundation Trust, Sheffield, United Kingdom.

Published: 1 October 2015

\section{Reference}

1. Kiely DG, Elliott CA, Sabroe I, Condliffe R: Pulmonary hypertension: diagnosis and management. BMJ 2013, 346:f2028, Apr 14.

\section{Submit your manuscript to a SpringerOpen ${ }^{\mathcal{O}}$ journal and benefit from:}

- Convenient online submission

- Rigorous peer review

- Immediate publication on acceptance

- Open access: articles freely available online

- High visibility within the field

- Retaining the copyright to your article 